\title{
Incidence of Myopia in Relation to Close Work at Indus Medical College Hospital, Tando Mohammad Khan
}

\author{
Nisar Ahmed Khan*, Aftab Ahmed Khan and Jawaid Iqbal Memon \\ Indus Medical College Hospital, Pakistan
}

Submission: January 25, 2017; Published: March 08, 2017

*Corresponding author: Nisar Ahmed Khan, Assistant Professor, Consultant ophthalmologist, Indus Medical College Hospital, Tando Mohammad Khan, Pakistan, Tel: +92-300-3014168; Email: nisargh2001@yahoo.com

\begin{abstract}
Incidence of Myopia in Relation to Close work at Indus Medical College Hospital, Tando Mohammad Khan

Purpose: To evaluate the incidence of myopia in relation with close near work particularly in those children involved in using small screen tablets and mobiles phones.
\end{abstract}

Material and methods: This study was conducted between January 2016 to June 2016 to know the incidence of myopic refractive error in children between 1 to 12 years in outpatient department of Indus medical college hospital and particularly the effect of close work like using tablets and mobile phones upon these children.We included 453 children who were diagnosed as myopic and having astigmatism , most of the children $322(71.08 \%)$ were using tablets and mobile while 131 (28.91\%) were not involve in using mobile and tablets. 197 (43.48\%) were boys while remaining $256(56.51 \%)$ were girls . They were divided into different age groups i.e. 60 (13.24\%) children, were in age group A, majority of children $230(50.77 \%)$ belonged to group B, $80(17.66 \%)$ were in age group C, $50(11.03 \%)$ in group D and 33(7.28\%) were in age group $\mathrm{E}$. All of the patients in groups $\mathrm{A}$ to $\mathrm{C}$ and those non co-operative from group $\mathrm{D}$ and $\mathrm{E}$ were under gone cycloplegic refraction.

Results: Out of 453 children 203(44.81\%) found to have myopia of up to -3.0D, 87(19.20\%) have myopia of up to $-2.0 \mathrm{D}, 67(14.79 \%)$ have myopia of up to $-4.0 \mathrm{D}$ and $96(21.19 \%)$ having myopia of $-1.0 \mathrm{D}$. majority of patients i.e. 301(66.44\%) having astigmatism of up to $-1 \mathrm{D}$, $83(18.32 \%)$ have astigmatism of up to $-2.0 \mathrm{D}, 52(11.47 \%)$ were having astigmatism of up to - 3.0D and $17(3.75 \%)$ having astigmatism of up to $-4.0 \mathrm{D}$. Majority of patients (though female ratio higher than male ratio) were having myopic astigmatism of up to $-1.0 \mathrm{D}$, in the age group $\mathrm{B}$ i.e. between ages of 3 to 5 years and were involved in using mobiles and tablets.

Conclusion: Myopia is the more prevalent refractive error all over the world in our study it is more prevalent in children between the ages 2 to 5 years of age particularly involved in close near work like apart from studying they were using mobiles and tablets particularly small screen for longer time. So better to use large screen avoid reading in dim light, do not use these small screens in lying position. Parents must take care while allowing the children to use mobiles and tablets screens must not be less than 12 inches in size better to allow them computers (desk top) rather than these small screens.

Keywords: Khan NA; Khan AA; Memon JI; Incidence of myopia in relation to close work at indus medical college hospital; Tando- Mohammad Khan

\section{Introduction}

Uncorrected refractive errors are a common cause of preventable blindness worldwide [1] and myopia is the result of complex hereditary and environmental factors, [2] most prevalent refractive error [3] defined as near sightedness caused by an incongruity between the power of the optical elements of the eye and its axial length. The object image is projected in front of the retina, and corrective lenses are necessary to displace the image backward, thus producing a clear retinal image. Although the causes of myopia are unclear, evidence supports both genetic and environmental components, among which are higher amounts of near work [4,5] years of education [6] and intelligence[7]. The world-wide urban rural patterns derived from both incidence and prevalence data are consistent with the near work hypothesis that increased reading and computer use may be a risk factor for myopia [5]. Researchers point to rigorous schooling system and the long hours children spend studying as being responsible for the high rates of myopia in Asia, rates that may be on the increase [8,9]. As myopia has onset and progression in childhood, it is important to focus research on these age groups. 


\section{Material and Methods}

This study was conducted between January 2016 to June 2016 at Indus Medical College Hospital to know the incidence of myopic refractive error in children between 1 to 12 years and particularly to know the effect of using tablets and mobile phones upon these children. We included 453 children who were diagnosed as myopic and having astigmatism , most of the children 322 (71.08\%) were using tablets and mobile while 131 (28.91\%) were not involve in using mobile and tablets, (Table 1). 197 (43.48\%) were boys while remaining 256 (56.51\%) were girls, (Table 2). They were divided into different age groups i.e. 60 $(13.24 \%)$ children were in age group A, majority of children 230 $(50.77 \%)$ belonged to group B, $80(17.66 \%)$ were in age group C, $50(11.03 \%)$ in group D and 33 (7.28\%) were in age group E, (Table 3). All of the patients in groups A to $C$ and those non co-operative from group D and E were under gone cycloplegic refraction.

\section{Table 1}

\begin{tabular}{|c|c|c|}
\hline $\begin{array}{c}\text { Total No. } \\
\text { of Patients } \\
\text { Diagnosed as } \\
\text { Myopic }\end{array}$ & $\begin{array}{c}\text { Using Mobile } \\
\text { Phones and } \\
\text { Tablets }\end{array}$ & $\begin{array}{c}\text { Not Using Mobile } \\
\text { Phones and } \\
\text { Tablets }\end{array}$ \\
\hline 453 & $322(71.08 \%)$ & $131(28.91 \%)$ \\
\hline
\end{tabular}

\section{Table 2}

\begin{tabular}{|l|l|l|}
\hline $\begin{array}{l}\text { Total No. of } \\
\text { Patients }\end{array}$ & Boys & Girls \\
\hline 453 & $197(43.48 \%)$ & $256(56.51 \%)$ \\
\hline
\end{tabular}

\section{Table 3}

\begin{tabular}{|c|c|c|}
\hline Groups & Age in Years & $\begin{array}{c}\text { No. of Patients } \\
\text { with \% }\end{array}$ \\
\hline A & $1-2$ yrs & $60(-13.24 \%)$ \\
\hline B & $3-5$ yrs & $230(50.77 \%)$ \\
\hline C & $6-8$ yrs & $80(-17.66 \%)$ \\
\hline D & $9-10 \mathrm{yrs}$ & $50(-11.03 \%)$ \\
\hline E & $11-12 \mathrm{yrs}$ & $33(-7.28 \%)$ \\
\hline
\end{tabular}

Results

Out of 453 children 203 (44.81\%) found to have myopia of up to $-3.0 \mathrm{D}, 87$ (19.20\%) have myopia of up to $-2.0 \mathrm{D}, 67(14.79 \%)$ have myopia of up to $-4.0 \mathrm{D}$ and $96(21.19 \%)$ having myopia of -1.0D (Table 4). Majority of patients i.e. 301 (66.44\%) having astigmatism of up to -1D, 83 (18.32\%) have astigmatism of up to $-2.0 \mathrm{D}, 52(11.47 \%)$ were having astigmatism of up to $-3.0 \mathrm{D}$ and $17(3.75 \%)$ having astigmatism of up to $-4.0 \mathrm{D}$ (Table 5 ).
Table 4

\begin{tabular}{|c|c|c|c|c|}
\hline $\begin{array}{c}\text { Range of } \\
\text { Myopia }\end{array}$ & Upto-3.0D & Upto-2.0D & Upto-4.0D & Upto-1.0D \\
\hline No. of Patients & 203 & 87 & 67 & 96 \\
$(44.81 \%)$ & $(19.20 \%)$ & $(14.79 \%)$ & $(21.19 \%)$ \\
\hline
\end{tabular}

Table 5

\begin{tabular}{|l|l|l|l|l|}
\hline Range of & $\begin{array}{l}\text { Upto - } \\
\text { Astigmatism }\end{array}$ & $\begin{array}{l}\text { Upto - } \\
\text { 1.0D }\end{array}$ & $\begin{array}{l}\text { Upto - } \\
\text { 3.0D }\end{array}$ & $\begin{array}{l}\text { Upto - } \\
4.0 \mathrm{D}\end{array}$ \\
\hline No. of Patients & 301 & 83 & 52 & 17 \\
& $(66.74 \%)$ & $(18.32 \%)$ & $(11.47 \%)$ & $(3.75 \%)$ \\
\hline
\end{tabular}

Majority of patients (though female ratio higher than male ratio) were having myopic astigmatism of up to $-3.0 \mathrm{D}$, in the age group B i. e. between ages of 3 to 5 years and were involved in using mobile phones and tablets.

\section{Discussion}

In our study we included only patients between ages 1 to 12 years, were involved in close near work for long time particularly spending more time on mobile phones and tablets apart from their study time. We found that out of 453 myopic patients the highest rate of myopia, $44.81 \%$ was in the age group B (3-5yrs) and particularly these children were involved in using mobile phone and tablets for longer time, in a study done in 2011 at Dow University Hospital Karachi Pakistan by Rasheed et al. [10] shows rate of myopia was $26.6 \%$ while a multicenter study done in China, Chile and Nepal that shows the prevalence rates of myopia were $16.2 \%, 5.8 \%$ and $0.3 \%$ in China.

Chile and Nepal respectively it is less than our study in another study the rate was almost same as our study that was conducted in Singapore and china, the prevalence rate of myopia in Singapore children was $36.7 \%$ compared to Xiamen (China) which was $18.5 \%$. Singapore has highly competitive educational system, whereas Xiamen school system is not so demanding, more near work activity may explain the difference in the prevalence rates [11,12]. An epidemiological study, concerning the prevalence of myopia among the student population (1518 years old) though the age is high as compare to our study of Northern Greece, myopia prevalence was $36.8 \%$ same as our results, It was found that myopia correlates strongly with near work and school performance [13]. Boys in orthodox Jewish schools were found to have higher rates of myopia (81.3\%) that is too high ratio as compared to our study while boys in general Jewish schools have only (27.4\%) myopia. Orthodox schooling is characterized by sustained near vision139and frequent change in accommodation due to the swaying habit during study [14]. In Xiamen, China the prevalence of myopia in urban school children was $19.3 \%$ and in rural school children was $6.6 \%$. The average hours per day children spent in reading and writing outside of school was 2.2 hours in the city compared with 1.6 hours in the country side. These data suggest the prevalence of myopia 
is higher in the city than in the country side. One possible explanation for these different rates could be that school children in the city spend more time reading and writing outside of school compared with children in the countryside. Myopic children in both the city and the countryside spent more time reading and writing compared with non myopic children. This increased near-work activity may contribute to the prevalence of myopia [15]. So the above studies prove same as ours that the time spent for close near work is directly related to the increase in prevalence of myopia with only change that children of this era are using mobile phones and tablets rather than only studying.

\section{Conclusion}

Myopia is the more prevalent refractive error all over the world in our study it is more prevalent in children between the ages 2 to 5 years of age particularly involved in close near work like, apart from studying they were using mobiles and tablets particularly small screen for longer time. So better to use large screen avoid reading in dim light, do not use these small screens in lying position. Parents must take care while allowing the children to use mobiles and tablets, screens must not be less than 12 inches in size better to allow them computers (desk top) rather than these small screens.

\section{References}

1. Tarcy-Hornoch k, Ying-Lai M, Varma R, Los Angeles Latino Eye Study Group (2006) Myopic refractive error in adult Latinos: Los Angeles Latino Eye Study. Invest Ophthalmol Vis Sci 47(5): 1845-1852.

2. Jack J Kanski (2011) Clinical Ophthalmology A systematic approach (7): 637.

3. Vitale S, Ellwein L, Cotch MF, Ferris FL, Sperduto R (2008) Prevalence of Refractive Error in United States, 1999-2004. Arch Ophthalmol 126(8): 1111-1119.

4. Saw SM, Chua WH, Hong CY, Wu HM, Chan WY et al. (2002) Near work in early-onsetmyopia. Invest Ophthalmol Vis Sci 43(2): 332-339.
5. Mutti DO, Mitchell GL, Moeschberger ML, Jones LA, Zadnik K (2002) Parental myopia, near work, school achievement, and children's refractive error. Invest Ophthalmol Vis Sci 43(12): 3633-3640.

6. Paritis N, Sarafidou E, Koiliopolus J, Trichopoulos D (1983) Epidemiologic research on the role of studying and urban environment in the development of myopia during school-age years. Ann Ophthalmol 15(11): 1061-1065.

7. Teasdale TW, Fuchs J, Goldshmidt E (1988) Degree of myopia in relation to intelligence and educational level. Lancet 2(8624): 13511354.

8. Tay MTH, Au Eong KG, Ng CY, Lim MK (1992) Myopia and educational attainment in 421, 116 young Singaporean males. Ann Acad Med 21(6): 785-791.

9. Zhao J, Pan X, Sui R, Munoz SR, Sperduto RD, et al. (2000) Refractive Error Study in Children: result from Shunyi District, China. Am J Ophthalmol 129(4): 427-435.

10. Rasheed A, Alkhairy S, Siddiqui F, Hassan M (2015) Prevalence of different refractive error and their relation to age and sex in patients presenting in out patient department of ophthalmology at Dow University of Health Sciences. Med Forum 26(1): 50-54.

11. Maul E, Barroso S, Munoz S, Sperduto RD, Ellwein LB (2000) Refractive error study in children: results from La Florida, Chile. Am J Ophthalmol 129(4): 445-454.

12. Pokharel GP, Negrel D, Munoz SR, Ellwein LB (2000) Refractive error study in children: results from Mechi Zone, Nepal. Am J Ophthalmol 129(4): 436-444.

13. Saw SM, Zhang MZ, Hong RZ, Fu ZF, Pang MH, et al. (2002) Near-work activity, night-lights, and myopia in the Singapore-China Study Arch Ophthalmol 120(5): 620-627.

14. Mavracanas TA, Mandalos A, Peios D, Golias V, Megalou K, et al. (2000) Basil Katsougiannopoulos Prevalence of myopia in a sample of Greek students Acta Ophthalmologica Scandinavica 78(6): 656-659.

15. Zylbermann R, Landau D, Berson D (1993) The influence of study habits on myopia in Jewish teenagers J Pediatr Ophthalmol Strabismus 30(5): 319-322.

Your next submission with Juniper Publishers will reach you the below assets

- Quality Editorial service

- Swift Peer Review

- Reprints availability

- E-prints Service

- Manuscript Podcast for convenient understanding

- Global attainment for your research

- Manuscript accessibility in different formats

(Pdf, E-pub, Full Text, Audio)

- Unceasing customer service

Track the below URL for one-step submission https://juniperpublishers.com/online-submission.php 